\title{
Lipase-producing ability of bacteria from inasua (fish fermented product) from Central Moluccas, Indonesia
}

\author{
LATUSI ANGGRIANI, SRI BUDIARTI, NISA RACHMANIA MUBARIK ${ }^{\boldsymbol{\nu}}$ \\ Department of Biology, Faculty of Mathematics and Natural Sciences, Institut Pertanian Bogor. Jl. Raya Dramaga, Bogor 16680, West Java, Indonesia. \\ Tel./fax.: +62-251-8622833. `email: nrachmania@apps.ipb.ac.id, latusianggriani@yahoo.com
}

Manuscript received: 22 September 2019. Revision accepted: 19 January 2020.

\begin{abstract}
Anggriani L, Budiarti S, Mubarik NR. 2020. Lipase-producing ability of bacteria from inasua (fish fermented product) from Central Moluccas, Indonesia. Biodiversitas 21: 622-628. One of fish preservation techniques through fermentation is Inasua which occurs spontaneously and involves various types of microorganisms. Isolates from Inasua are believed to have the ability to produce lipolytic enzymes. The purpose of this study was to identify potential bacterial isolates isolated from Inasua and to determine their lipase producing ability. The confirmation test of lipase-producing ability was conducted by inoculating the microbes into media containing Nutrient agar (NA), olive oil, and rhodamin-B. Lipolytic bacteria were detected using a screening method with UV light. From the results, there were 5 isolates of bacteria that showed lipolytic activity as IG 3.1, IG 6, IG 10, IG 12, IG 66. Lipase assay was determined using spectrophotometric method with p-nitrophenyl palmitate (pNPP) as a substrate and titration method with olive oil as a substrate. The enzyme showed maximum activity at pNPP as a substrate. IG 6 and IG 12 gave the highest activity from lipase assay. Growth and production curves were created before partial purification was carried out. The results of the curves showed that the optimum activity of

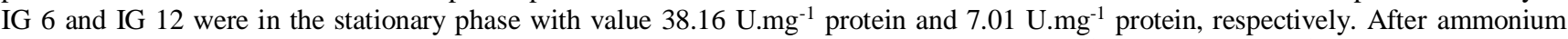
sulfate precipitation, the activity of the lipase IG 6 and IG 12 were found to be $39.65 \mathrm{U}^{-\mathrm{mL}^{-1}}$ and $37.05 \mathrm{U} . \mathrm{mL}^{-1}$, respectively. During optimization, the enzyme showed maximum activity at $\mathrm{pH} 8 / 70^{\circ} \mathrm{C}$ temperature. Molecular identification by using the $16 \mathrm{~S}$ rRNA gene and phylogenetic analysis showed that isolates IG 6 and IG12 are closely related to Bacillus paramycoides and Bacillus kochii, respectively.
\end{abstract}

Keywords: 16S rRNA gene, Bacillus, fish fermented, lipase-producing

\section{INTRODUCTION}

Lipase is a group of hydrolase enzymes that performs a multitude of roles in daily life. These enzymes are used extensively in food industry (Muthumari et al. 2016). The human body uses lipase to break down fat during digestion of food in the digestive system (Kumar et al. 2017). Lipases are produced by animals, humans, plants, and even microorganisms (Thakur 2012). The microorganism lipases are more useful because its can be produced in large amounts in shorter periods of time (Gopinath et al. 2013). Aspergillus niger (Salihu et al. 2016), A. flavus, Alternaria sp., Penicillium sp. (Wadia and Jain 2017), Bacillus subtilis (Chaturvedi et al. 2010), GeoBacillus stearothermophilus (Ekinci et al. 2015), and Lactobacillus sp. (Rashmi and Gayathri 2014) have ability to produce lipase.

Microorganisms from Thai fermented fish (Pekasam) (Daroonpunt et al. 2018) and shrimp paste (Ka-pi) (Daroonpunt et al. 2019) have been reported as lipolytic bacteria. In Indonesia, there are many kinds of fermented foods. One of fermented foods from Indonesia is Inasua made up of fermented fish from Central Moluccas, Indonesia. Inasua is processed using salt coconut sap without any inoculum (Nara et al. 2013). The fish species typically used are oil fish (Ruvettus pretiosus Cocco). The skin of this fish is thick and oily (Ling et al. 2009). Some bacteria have been successfully isolated from Inasua, including L. plantarum IN05, L. rhamnosus IN13, IG 3.1, IG 6, IG 10, IG 12, and IG 66 (Mahulette et al. 2016; Amaliah 2017). Jaeger et al. (1994) said that lipolytic bacteria can be found in oily environments, so that isolates from Inasua have the potential to produce lipases. The biodiversity of microorganisms involved in the Inasua needs to explore the beneficial health effect. The aim of this research was to identify the isolates potential bacteria from inasua and to determine their lipase producing ability.

\section{MATERIALS AND METHODS}

\section{The selection of lipase-producing bacteria}

Seven isolates in this study were selected based on previous studies, including $L$. plantarum IN05, $L$. rhamnosus IN13, IG 3.1, IG 6, IG 10, IG 12, and IG 66 (Mahulette et al. 2016; Amaliah 2017). Bacterial isolates were inoculated in Nutrient Agar (NA) and de Man Ragosa Agar (MRSA) media for 24 hours. After that, the bacterial culture was inoculated into media with $1 \%$ Rhodamine B and $1 \%$ olive oil $+2 \%$ PVA (1:3) (Kouker and Jaeger 1987), then incubated for $24-48$ hours at $37^{\circ} \mathrm{C}$ temperature. After 24-48 hours, it was observed under UV light (365 $\mathrm{nm})$. 


\section{Crude enzyme extract production}

One loop of isolates was inoculated into $20 \mathrm{~mL}$ of Nutrient Broth (NB) medium and then incubated for 24-48 $\mathrm{h}$ at $27{ }^{\circ} \mathrm{C}$ temperature. Inoculum was inoculated into 100 $\mathrm{mL}$ of NB medium with $1 \%$ olive oil then incubated for 24 $\mathrm{h}$ at $27{ }^{\circ} \mathrm{C}$ temperature. The cultures yielded were centrifuged at $10000 \mathrm{rpm}(595 \mathrm{~g})$ for 10 minutes at $4{ }^{\circ} \mathrm{C}$ temperature to obtain supernatant. The crude enzymecontaining supernatant was removed into Falcon conical tube for lipase unit activity measurement.

\section{Lipase assay}

Lipase activity test was carried out through titration and spectrophotometry methods. In titration method was done by employing olive oil was employed as a substrate. $4 \mathrm{ml}$ of the substrate was mixed with $2 \mathrm{ml}$ of phosphate buffer $0.1 \mathrm{M} \mathrm{pH}$ 7, $2.5 \mathrm{ml}$ distilled water, $0.5 \mathrm{ml} 0.1 \mathrm{M} \mathrm{CaCl}_{2}$, and $1 \mathrm{ml}$ of crude extract enzyme which then incubated for 15 minutes in a shaking incubator at $27{ }^{\circ} \mathrm{C}$ temperature. The reaction was stopped by adding $1 \mathrm{ml}$ of absolute ethanol $96 \%$. The mixture was titrated with $0.05 \mathrm{M} \mathrm{NaOH}$ using phenolphthalein indicator. One unit of lipase activity was defined by the number of enzymes that produce $1 \mu \mathrm{mol}$ of fatty acid per minute (Xu et al. 2002).

In spectrophotometry method p-nitrophenyl palmitate (pNPP) was used as a substrate. $30 \mathrm{mg}$ pNPP was dissolved in $10 \mathrm{ml}$ of isopropanol (Solution A), after that, solution B (phosphate buffer $\mathrm{pH} 7,0.1 \mathrm{M}$ ) was prepared. Solution A is then mixed with solution B as much as $90 \mathrm{ml}$ (substrate). $0.5 \mathrm{ml}$ crude extract enzyme was reacted with $2 \mathrm{ml}$ substrate and incubated for 30 minutes at $27{ }^{\circ} \mathrm{C}$ temperature. After 30 minutes, $50 \mu \mathrm{l}$ Triton X-100 was added. The absorbance of the solution was measured using a spectrophotometer (410 nm) (Gupta et al. 2003).

\section{Establishment of growth and production curves}

Two loops of bacterial culture from NA slant were grown on $40 \mathrm{~mL} \mathrm{NB}$ medium with olive oil. The culture was incubated for $7 \mathrm{~h}$ (absorbance $=0.8$ ) in shaking incubator at $27{ }^{\circ} \mathrm{C}$ temperature. Lipase was produced by inserting $1 \%$ of bacterial inoculum from the culture into $200 \mathrm{~mL}$ NB medium with olive oil. Cell density was measured at a wavelength of $600 \mathrm{~nm}$ with a spectrophotometer every $3 \mathrm{~h}$ for $51 \mathrm{~h}$ to establish a growth curve. Enzyme was produced in every time segment to establish a production curve. The lipase activity was then measured by spectrophotometry.

\section{Partial purification of lipase with ammonium sulfate}

For purification precipitation was conducted to determine the optimum fraction with saturation of ammonium sulfate (Scopes, 1994). An ammonium sulfate concentration series from $0 \%$ to $100 \%$ was used in crude enzyme purification. The purified lipase was stored at $4{ }^{\circ} \mathrm{C}$ temperature for $24 \mathrm{~h}$ then centrifuged at $6000 \mathrm{rpm}$ for 30 min. The precipitate yielded was solved in $0.1 \mathrm{M}$ phosphate buffer $\mathrm{pH} 7$ in a volume of $2 \mathrm{~mL}$. Afterward, the lipase activity and protein content were subjected to testing by Bradford's method (Bradford 1976).

\section{Lipase characterization}

Lipase characterization covered optimum $\mathrm{pH}$ and temperature. The optimum $\mathrm{pH}$ was determined by reacting the enzyme with pNPP substrate at $\mathrm{pH} 3-9$, while the optimum temperature was determined by testing at 10-80 ${ }^{\circ} \mathrm{C}$. In every optimization test, the lipase activity was measured by spectrophotometry.

\section{Identification of $16 \mathrm{~S}$ rRNA gene}

Two isolates with the highest lipase activity were inoculated in (1 loop) a tube containing NB. Later, the culture was developed for 24 hours at room temperature using a shaker. The developed culture was then transferred to a $1.5 \mathrm{~mL}$ tube and centrifuged twice at $13000 \mathrm{rpm}$ for 1 minute. The formed supernatant was removed and DNA extraction was carried out on a settled pellet using a Geneaid kit. After that, $5 \mu$ LGoTaq Green Master Mix2xwas added to 1 pmol DNA sample, 1 pmol $63 \mathrm{~F}$ or $38 \mathrm{~F}$ primer and 1 pmol $1387 \mathrm{R}$, respectively. The identification process was carried out by amplifying the $16 \mathrm{~S}$ rRNA encoding gene using a $63 \mathrm{~F}$ primer $\left(5^{\prime}-\mathrm{CAG}\right.$ GCC TAA CAC ATG CAA GTC-3') and 1387R (5'-GGG CGG WGT GTA CAA GGC-3') on PCR machines (Marchesi et al. 1998). The first stage of PCR process was (pre-denaturation) processed with a temperature of $94{ }^{\circ} \mathrm{C}$ for 4 minutes, followed by 35 cycles consisting of denaturation at $94{ }^{\circ} \mathrm{C}$ for 30 seconds, annealing at $55{ }^{\circ} \mathrm{C}$ for 45 seconds, and elongation process at $72{ }^{\circ} \mathrm{C}$ for 1 minute 30 seconds. PCR process was completed by postelongation at $72{ }^{\circ} \mathrm{C}$ for 10 minutes and cooling at $4{ }^{\circ} \mathrm{C}$ for 5 minutes. The PCR product was electrophoresed on $1 \%$ agarose gel in a TAE $1 \mathrm{x}$ buffer with a $90 \mathrm{~V}$ voltage for 60 minutes. DNA bands were stained with Ethidium Bromide (EtBr) $5 \mu \mathrm{g} / \mathrm{mL}$ and visualized using UV light. PCR products would be sequenced using services from $1^{\text {st }}$ Base Malaysia.

The DNA sequences obtained were analyzed and determined homologically in GenBank through the Basic Local Alignment Search Tool (BLAST) program at (http://www.ncbi.nml.nih.gov). By attaching a reference sequence from the results of BLAST, a phylogenetic tree was constructed using MEGA $X$ application. The phylogenetic tree is made using the maximum likelihood method and the best fit model with bootstrap (BS) 1000x. Isolates with the same identity as taxons in one group with BS values $\geq 70$ showed close kinship. Then the DNA sequence is submitted to the GenBank database to get the access number.

\section{RESULTS AND DISCUSSION}

\section{Lipolytic bacteria selection with olive oil substrate and cell characterization}

Lipolytic bacteria are able to produce lipase. These bacteria can be detected by observation of cell luminescence on the substrate medium that contained rhodamine-B and olive oil. Bacteria with lipase production capability will luminate in UV light (Kouker and Jaeger 1987) (Figure 1). 


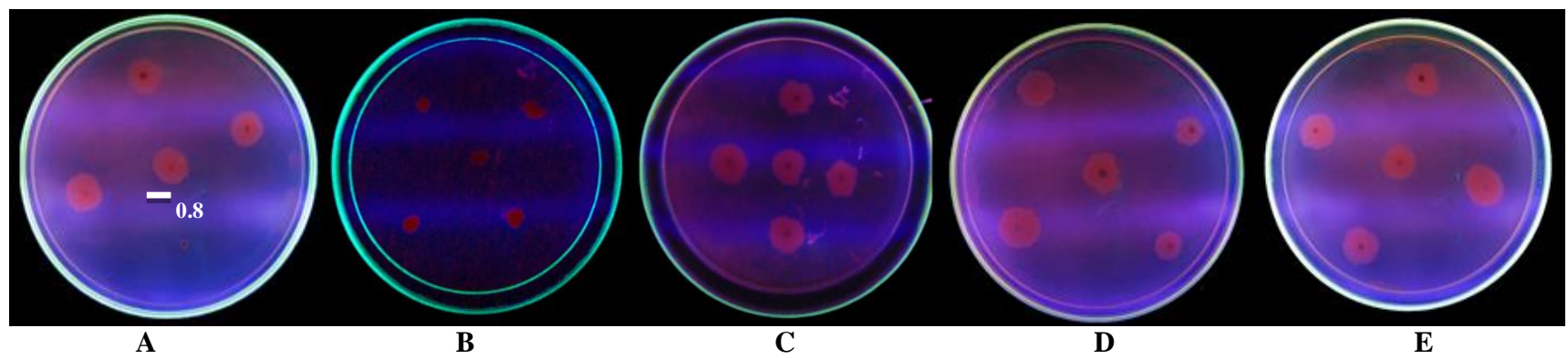

Figure 1. Lipolytic activity of IG 3.1 (A), IG 6 (B), IG 10 (C), IG 12 (D), IG 66 (E) on the Rhodamin-B-containing olive oil substrate on UV light

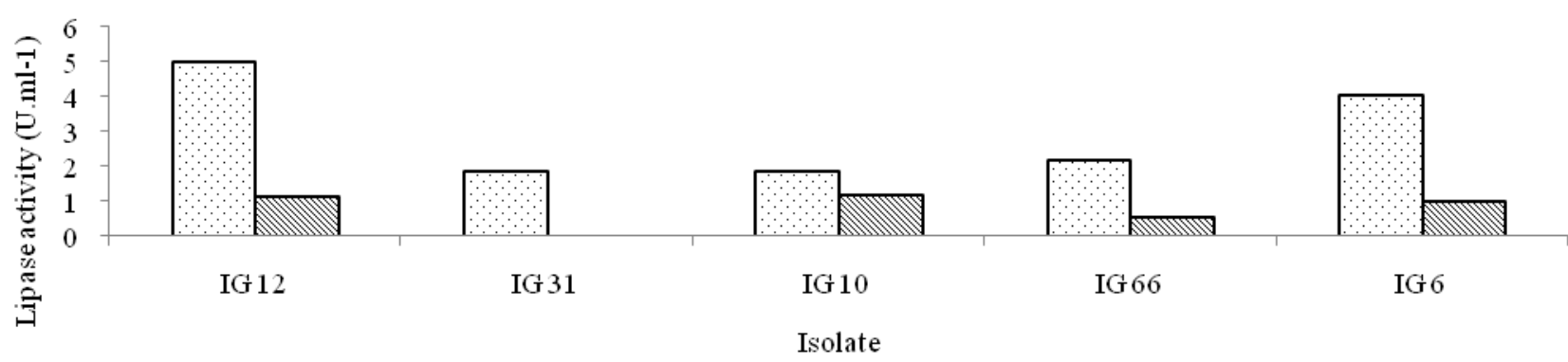

$\square$ pNPP $\triangle$ Olive oil

Figure 2. Lipase activity of the crude extract of every lipolytic isolate on the $p$ NPP and olive oil substrates

It was found that 24-hour incubation at room temperature, $70 \%$ of the isolates collected from Inasua exhibited lipolytic activity as marked with a glow on the rhodamin-B medium when observed under UV light at wavelength of $365 \mathrm{~nm}$. All of the bacteria that demonstrated lipolytic activity were selected by measuring enzyme activity with spectrophotometry and titration because the methods used to measure lipolytic activity in this research lack the ability to yield activity value in quantity.

\section{Lipase activity in lipase crude extract}

Lipase activity testing was conducted to obtain bacterial isolates with the highest potential. This research employed methods of titration and spectophotometry to measure the enzyme activity in the crude extract. Isolates IG6 and IG12 had the greatest potential for having scored the highest in the enzyme activity in the crude extract (Figure 2). Both isolates scored the highest in both methods used. The titration method showed a change in color into pinkish with addition of phenolphthalein indicator. When $\mathrm{NaOH}$ was added, nothing was left to bind to fatty acids, which are weak acids, hence the solution $\mathrm{pH}$ increase $(\mathrm{Xu}$ et al. 2002).
In the spectrophotometry method, meanwhile, lipase activity was measured with pNPP substrate that was incubated for $30 \mathrm{~min}$ at $37{ }^{\circ} \mathrm{C}$ temperature prior to spectrophotometric visualization $(410 \mathrm{~nm})$. The absorbance rate measured was converted using a standard pnitrophenol ( $\mathrm{pNP}$ ) curve for lipase activity. Lipase activity is defined as $\mu \mathrm{mol}$ of $\mathrm{pNP}$ formed per minute (Becker et al. 1997). The paranitrophenol produced turned the solution into yellow, indicating that the solution's $\mathrm{pH}$ shifted alkaline-bound (Pencreac'h and Baratti 1996).

\section{Establishment of growth and production curves}

Cell growth and lipase production curves of the two isolates were established at $\mathrm{pH} 7$ at ambient temperature to find out about the optimum lipase production time. The two isolates with the highest lipase activity were selected for optimum lipase activity testing. The results showed that isolates IG12 and IG 6 (Figure 3) displayed optimum lipase activity at the $36^{\text {th }}$-hour of incubation with values of 7.01 and $38.16 \mathrm{U} \cdot \mathrm{mg}^{-1}$ protein, respectively. This suggests that the most optimum of both isolates' activity was apparent at the $36^{\text {th }}$ hour of incubation. 


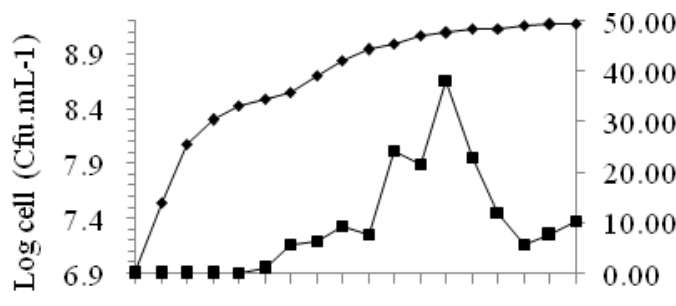

03691215182124730333394245481

Time (Hour)

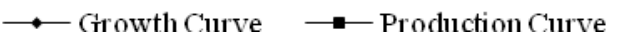

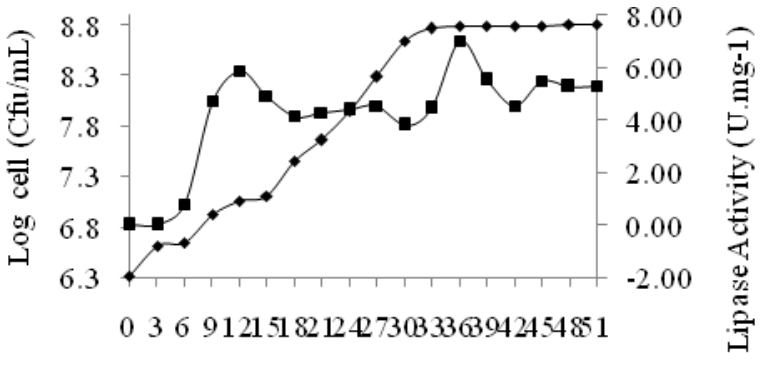

Time (Hour)

A

Figure 3. Growth and lipase enzyme production curves of isolates IG6 (A) and IG12 (B) at $27^{\circ} \mathrm{C}$ temperature, pH 7 during 51 hours under shaking

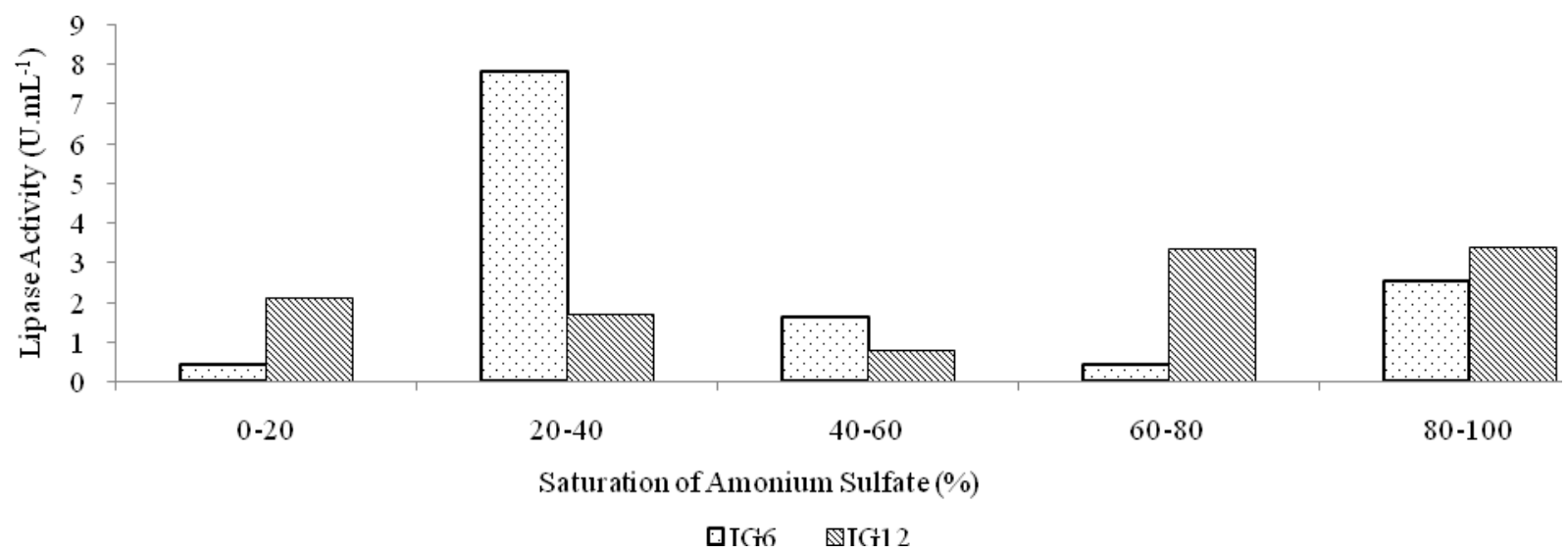

Figure 4. Lipase partial purification of IG6 and IG12 with ammonium sulfate

Table 1. Fold purification enzyme IG 6 and IG 12

\begin{tabular}{|c|c|c|c|c|c|c|}
\hline Source & $\begin{array}{c}\begin{array}{c}\text { Volume } \\
(\mathrm{mL})\end{array} \\
\end{array}$ & $\begin{array}{c}\text { Total protein } \\
\text { (mg) }\end{array}$ & $\begin{array}{c}\text { Enzyme activity } \\
\text { (Unit) }\end{array}$ & $\begin{array}{c}\text { Specific activity } \\
\left(\mathbf{U}^{-m^{-1}}\right)\end{array}$ & $\begin{array}{c}\text { Fold } \\
\text { purification }\end{array}$ & $\begin{array}{c}\text { Yield } \\
(\%)\end{array}$ \\
\hline & & & IG 6 & & & \\
\hline Crude enzyme & 200 & 20.07 & 276.8 & 13.79 & 1 & 100 \\
\hline $40 \%$ & 10 & 1.18 & $\begin{array}{l}77.94 \\
\text { IG } 12\end{array}$ & 66.12 & 4.79 & 28.16 \\
\hline Crude enzyme & 200 & 20.68 & 92.72 & 4.48 & 1 & 100 \\
\hline $100 \%$ & 10 & 1.004 & 33.64 & 33.52 & 7.49 & 36.33 \\
\hline
\end{tabular}

\section{Partial purification of lipase with ammonium sulfate}

Enzyme precipitation with ammonium sulfate was performed to purify the enzyme produced. The precipitate from the crude enzyme extract took the form of supernatant from production medium. From the ammonium-sulfateassisted enzyme precipitation, it was found that the lipase produced had the highest precipitation activity at $40 \%$ ammonium sulfate saturation for IG6 lipase and 100\% for IG12 lipase (Figure 4).

Enzyme activity has increased after partial purification (Table 1). The specific activity of IG 6 lipase in the $40 \%$ fraction reached $66.12{\mathrm{U} . \mathrm{mg}^{-1}}$ with a purity level of 4.79 times that of the crude enzyme. Lipase IG 12 has a lipase activity value of $33.52{\mathrm{U} . \mathrm{mg}^{-1}}^{-}$at $100 \%$ fraction with a purity level of 7.49 times that of the crude extract enzyme.

\section{pH and temperature optimum}

The optimum $\mathrm{pH}$ and temperature were determined by purification with highest precipitation activity. The purification IG 6 and IG 12 lipase showed optimum activity at $\mathrm{pH} 8$ and $70^{\circ} \mathrm{C}$ temperature (Figure 5). IG 6 and IG 12 lipase reached the maximum lipase activity 39.65 $\mathrm{U} / \mathrm{mL}^{-1}$ and $37.05 \mathrm{U} \cdot \mathrm{mL}^{-1}$, respectively, at $70{ }^{\circ} \mathrm{C}$ temperature and $\mathrm{pH} 8$. 


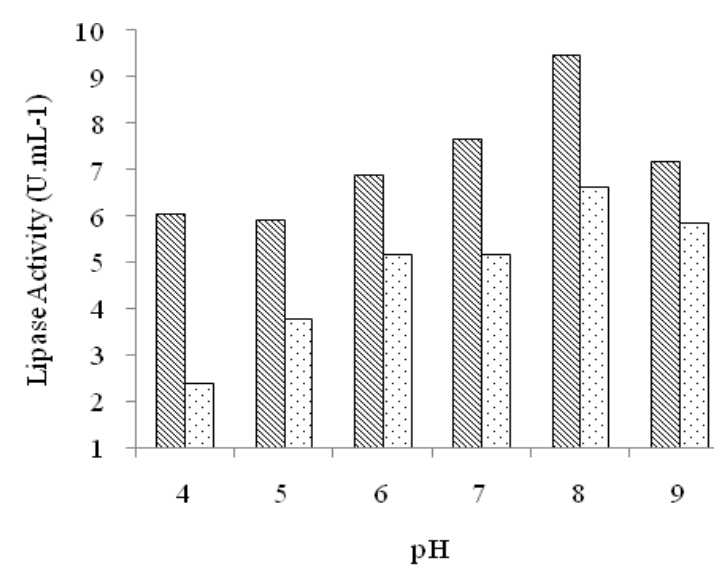

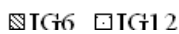

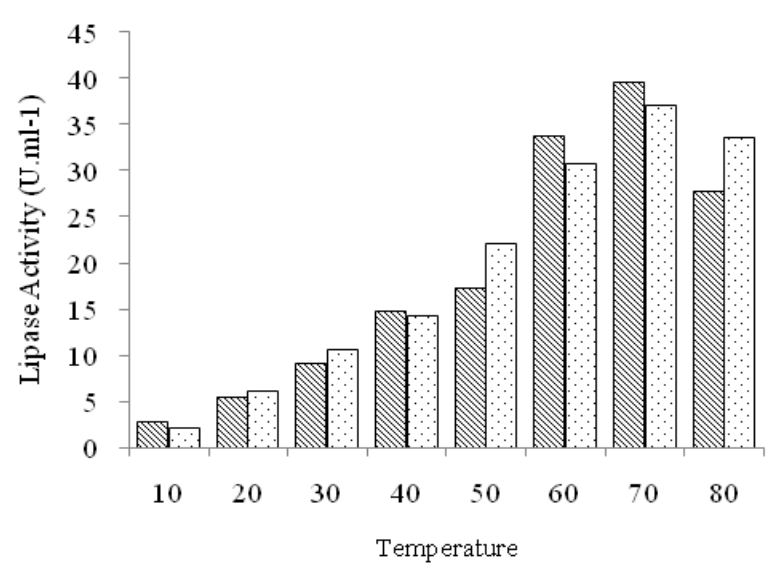

$\mathbb{N I G 6} \square \mathrm{IG} 12$

\section{A}

\section{B}

Figure 5. Lipase activity of isolates IG6 and IG12 at variable pH (Citrate buffer of pH 4, phosphate buffer of pH 5-7, Tris-HCL buffer of $\mathrm{pH} 8$-9) (A) and temperatures at $\mathrm{pH} 8$ (B)

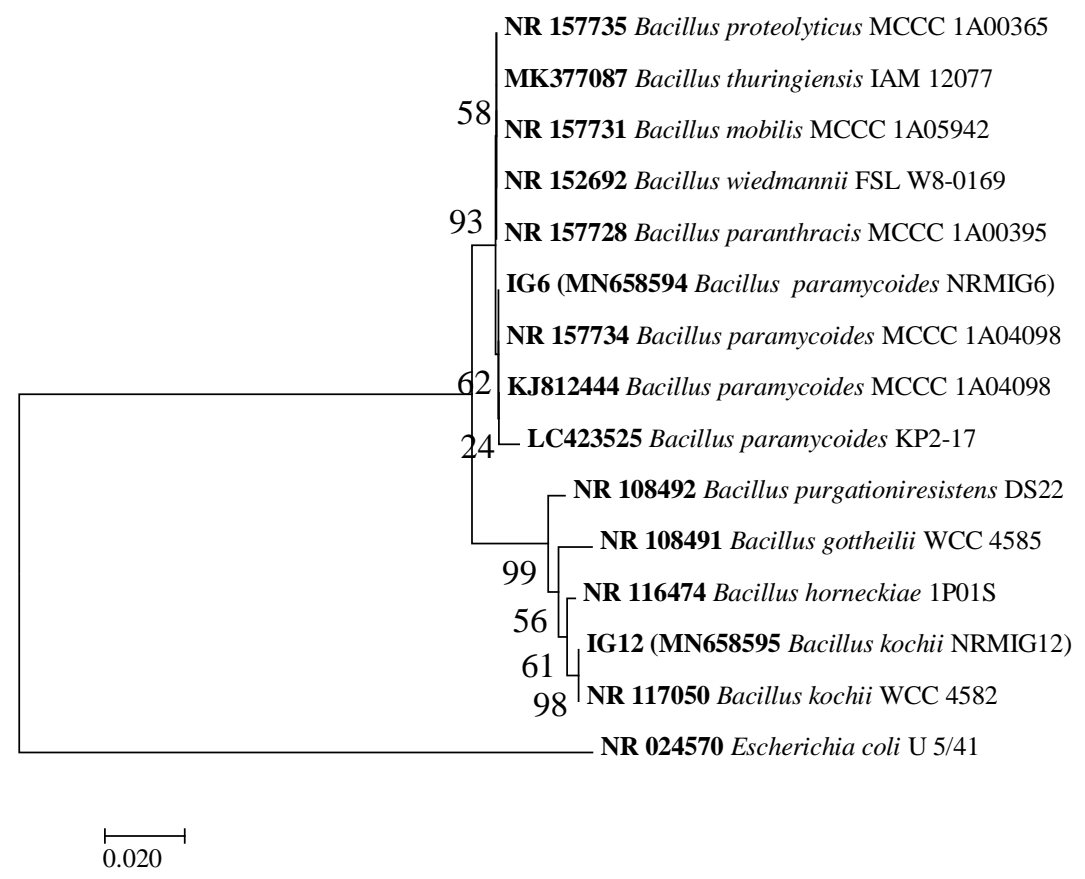

Figure 6. Phylogenetic tree base on 16S rRNA genes of the IG 6 and IG 12. The percentage of bootstrap values was shown by the number at each branch point.

Table 2. Bioinformatics analysis from NCBI of isolates IG6 and IG12 by 16S rRNA gene sequences

\begin{tabular}{lllll}
\hline Isolate & Species & Strain & Similarity & Accesion number \\
\hline IG 6 & Bacillus paramycoides & MCCC 1A04098 & $99.82 \%$ & NR 157734 \\
& Bacillus thuringiensis & IAM12077 & $99.64 \%$ & MK377087 \\
& Bacillus parantrhracis & MCCC1A00395 & $99.64 \%$ & NR 157728 \\
& Bacillus wiedmannii & FSLW80169 & $99.55 \%$ & NR 152692 \\
& Bacillus mobilis & MCCC1A05942 & $99.55 \%$ & NR 157731 \\
& & & & NR 117050 \\
IG 12 & Bacillus kochii & WCC 4582 & $99.72 \%$ & NR 108491 \\
& Bacillus gottheilii & WCC 4585 & $98.59 \%$ & NR 116474 \\
& Bacillus horneckiae & NR 1S 108492 \\
\hline
\end{tabular}




\section{S rRNA gene sequencing}

Two selected isolates were identified using the $16 \mathrm{~S}$ rRNA genes. The amplified 16S rRNA genes were verified by electrophoresis, showing 1300 bp DNA strands. PCR amplification of isolates IG6 and IG12 used primers 63F and 1387R. The DNA strands of the two isolates that were visible in UV light during the electrophoresis process belonged to the 1000-1500-bp range. The resulted PCR was then sequenced using $1^{\text {st }}$ Base Malaysia's service. The best analysis results showed that isolates IG6 and IG12 compare with another species bore $99.82 \%$ similarity to $B$. paramycoides and $99.72 \%$ to $B$. kochii, respectively (Table 2 ). The results of submitting DNA sequences obtained access numbers and strain isolates. IG 6 is a species of $B$. paramycoides strain NRMIG6 with access number MN658594. IG 12 is a B. kochii strain NRMIG12 species with access number MN658595.

The Phylogenetic tree was constructed by the neighborjoining method and Kimura-2 Parameter model in MEGA $\mathrm{X}$ application. Bootstrap values base on 1000 replications (Figure 6).

\section{Discussion}

The olive oil present in the medium was hydrolized by lipase and bound to Rhodamine-B, causing the bacteria to illuminate in UV light (Kouker and Jaeger 1987). Lipid generally induced lipase production (Rathi et al. 2001). Olive oil was used in this study as inducer for lipase production. Olive oil, according to Zouaoui and Bouziane (2011), is one of the best inducers for lipase production by bacteria. Isolates IG6 and IG12 gave the highest activity from lipase assay. From the measurement results, it can be seen that the IG 6 and IG 12 yielded the highest lipase activity in the stationary phase. Base on 16S rRBA gene sequence similarity, the isolate IG6 showed that $99.82 \%$ similarity with $B$. paramycoides MCCC 1A04098, while the isolate IG12 was closely related to B. kochii WCC 4582 with $99.72 \%$.

The highest activity for IG6 lipase partial purification reached $39.65 \mathrm{U}_{\mathrm{mL}}^{-1}$ at $\mathrm{pH} 8 / 70{ }^{\circ} \mathrm{C}$ temperature. The IG12 lipase partial purification reached the highest activity of 37.05 U.ML ${ }^{-1}$ at $\mathrm{pH} 8$ and $70{ }^{\circ} \mathrm{C}$ temperature. The optimum $\mathrm{pH}$ and temperature for the lipase from Bacillus sp. THL027 nearly resembles those of IG6 and IG12 lipase. Bacillus sp. THL027 has the optimum crude enzyme activity of 7 U.mL $\mathrm{mL}^{-1}$ at $70{ }^{\circ} \mathrm{C}$ temperature and $\mathrm{pH} 7$ (Dharmsthiti and Luchai 1999). This also accords with previous research, which showed that B. Paramycoides from Thai prawn paste has lipase activity of $22 \mathrm{U} . \mathrm{mL}^{-1}$ (Daroonpunt et al. 2019). B. kochiiwas only reported by Seiler et al. (2012) as producing fatty acids from esterase lipase (C8) process. However, the result of lipaseproducing ability of $B$. kochii has not previously been described.

Ammonium sulfate's role in the precipitation process was to separate protein compounds from non-protein ones. The protein in the substrate was precipitated by ammonium sulfate as protein molecules were bigger in size. Besides, this precipitation process would also maximize the enzyme's concentration. Protein precipitated to different salt concentrations. Hydrophobic proteins precipitated to lower salt concentrations, while hydrophilic proteins required higher salt concentrations (Scopes 1994). Purification IG 6 and IG 12 lipase showed maximum activity at $70{ }^{\circ} \mathrm{C}$ temperature and $\mathrm{pH} 8$ (Tris-HCL buffer). The IG 6 and IG 12 lipase activity showed lower results compared to lipase activity from Pseudomonas sp. ADT3

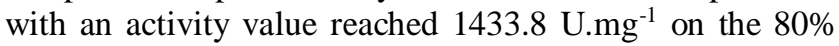
ammonium sulfate with fold purification 2.9 from the crude extract enzyme (Dey et al. 2014). The lipase activity decreased significantly at $10{ }^{\circ} \mathrm{C}$ temperature. It was also highly active in $20-80{ }^{\circ} \mathrm{C}$ temperature. According to Janssen et al. (1994), thermal stability is one of the bacterial lipases outplay characteristics because pancreatic lipase loses its activity at a temperature above $40{ }^{\circ} \mathrm{C}$ temperature. This is nearly close to lipase reported from Bacillus sp. (Dharmsthiti and Luchai 1999) and $B$. thermoleovorans ID-1 (Lee et al. 1999). Every bacterial lipase has unique optimum $\mathrm{pH}$ and temperature. The optimum $\mathrm{pH}$, which is influenced by the charges of amino acid side chains, allows a suitable condition, accelerating the reaction an enzyme is undergoing (Sumarlin et al. 2013). Bacterial lipase activity traditionally remains stable within $\mathrm{pH}$ range 6 through 8 and declined if the $\mathrm{pH}$ exceeds 8 (Handayani et al. 2011). Lestari et al. (2009) stated that the lipase activity outside the optimum $\mathrm{pH}$ remained lower because the enzyme is denaturated.

Environmental factors like temperature influences the lipase production. As explained by Handayani et al. (2011), lipase activity goes down if lipase is incubated at temperatures below or above the optimum ones. Low temperatures lower the enzyme-substrate complex formation speed, limiting the complex, and the product, production to only small amounts. By contrast, temperature increase up to the optimum one can increase the enzymesubstrate complex formation, thus also elevating the enzyme activity. The enzyme-substrate complex formation speed is highly effective at the optimum temperature, and as a result, the product produced increase in quantity as well. If the temperature keeps increasing beyond the optimum one, the enzyme activity again lowered down. The enzyme undergoes denaturation and changes in its three-dimensional structure, causing difficulty for the substrate to bind the active side of the enzyme and, thus, lowered enzyme activity.

Five bacterial isolates isolated from Inasua showing the ability to produce lipase. IG 6 and IG 12 were the potential isolates because of their highest activity. Base up-on the 16S rRNA gene sequence similarity, IG 6 was closely related to $B$. paramicoides with $99.82 \%$ and IG 12 showed that similarity $99.72 \%$ with B. kochii.

\section{ACKNOWLEDGEMENTS}

This research was granted by the Ministry of Research, Technology and Higher Education Republic Indonesia number No. 6E/KPT/2019 on 14 February 2019 and contract number No. 3/E1/KP.PTNBH/2019 on 29 March 2019 to corresponding author. 


\section{REFERENCES}

Amaliah P. 2017. Isolation and selection of proteolytic, halotolerant bacteria from Inasua and characterization of the protease activity. [Hon. Thesis]. IPB University, Bogor. [Indonesian]

Becker P, Abu-Reesh I, Markossian S, Antranikian G, Markl H. 1997. Determination of the kinetic parameters during continuous cultivation of the lipase-producing thermophile Bacillus sp. IHI-91 on olive oil Appl Microbiol Biotechnol 48: 184-190.

Bradford MM. 1976. A rapid and sensitive method for the quantitation of microgram quantities of protein utilizing principles of protein-dye binding. Anal Biochem 72 (2): 248-254.

Chaturvedi M, Singh M, Chugh MR, Rahul K. 2010. Isolation of lipase producing bacteria from oil-contaminated soil for the production of lipase by solid-state fermentation using coconut oil cake. Intl J Biotech Biochem 6 (4): 585-594.

Daroonpunt R, Saeng-in P, Tanasupawat S. 2019. Identification and lipolytic activity of Bacillus and Staphylococcus strain from shrimp paste (Ka-pi). J Appl Pharm Sci 9 (4): 024-029

Daroonpunt R, Tanaka N, Uchino M, Tanasupawat S. 2018 Characterization and screening of lipolytic bacteria from Thai fermented fish. Sains Malaysiana 47 (1): 91-97.

Dey A, Chattopadhyay A, Mukhopadhyay SK, Saha P, Chatterjee S, Mait TK, Roy P. 2014. Production, partial purification, and characterization of an extracellular psychrotrophic lipase from Pseudomonas sp. ADT3. J Bioremed Biodeg 5 (6): 1-8.

Dharmsthiti S, Luchai S. 1999. Production, purification and characterization of thermophilic lipase from Bacillus sp. THL027. FEMS Microbiol Lett 179: 241-246.

Ekinci AP, Dincer B, Baltas N, Adiguzel A. 2015. Partial purification and characterization of lipase from GeoBacillus stearothermophilus AH22. J Enzyme Inhib Med Chem 31 (2): 325-331.

Gopinath SCB, Anbu P, Lakshmipriya T, Hilda A. 2013. Strategies to characterize fungal lipases for applications in medicine and dairy industry. Biol Med Res. DOI:10.1155/2013/154549.

Gupta R, Rathi P, Gupta N, Bradoo S. 2003. Lipase assay for conventional and molecular screening: an overview. Biotechnol Appl Biochem 37: 63-71.

Handayani SN, Lestari P, Oedjijono, Raharjo TJ, Matsjeh S. 2011. Characterization of the biochemical properties of the crude extract extracellular lipase of the bacterium Azospirillum sp. PRD1. Molekul $6(2): 74-83$

Jaeger KE, Ransac S, Dijkstra BW, Colson C, van Heuvel M, Misset O. 1994. Bacterial lipases. FEMS Microbiol Rev 15 (1994): 29-63.

Janssen PH, Monk CR, Morgan HW. 1994. A thermophilic, lipolytic Bacillus sp. and continuous assay of its p-nitrophenyl-palmitate esterase activity. FEMS Microbiol Lett 120: 195-200.

Kouker G, Jaeger KE. 1987. Specific and sensitive plate assay for bacterial lipases. Appl Environ Microbiol 53: 211-213.

Kumar A, Verma U, Khongwir AD. 2017. Production and characterization of lipase enzyme from Lactobacillus. EJPMR 4 (1): 317-321.

Lee O-W, Koh Y-S, Kim K-J, Kim B-C, Choi H-J, Kim D-S, Suhartono MT, Pyun Y-R. 1999. Isolation and characterization of a thermophilic lipase from Bacillus thermoleovorans ID-1. FEMS Microbiol Lett 179: 393-400

Lestari P, Handayani SN, Oedjijono. 2009. Characterization of the biochemical properties of the crude extract extracellular lipase of the bacterium Azospirillum sp. JG3. Molekul 4 (2): 73-82.

Ling KH, Nichols PD, But PPH. 2009. Fish-induced keriorrhea. In: Taylor SL, editor. Advances in Food and Nutrition Research Volume 57. Academic Press, Amsterdam.

Mahulette F, Mubarik NR, Suwanto A, Widanarni. 2016. Isolation and characterization of lactic acid bacteria from Inasua. J Trop Biol Biotechnol 1 (2): 71-76.

Marchesi ST, Weightman AJ, Martin TA, Fry JC, Hiom SJ, Dymock D, Wade WG. 1998. Design and evaluation of useful bacterium specific PCR primer that amplify genes coding for bacterial 16S rRNA. Appl Environ Microbiol 64 (6): 795-799.

Muthumari GM, Thilagavathi S, Hariram N. 2016. Industrial enzymes: lipase producing microbes from waste volatile substances. Intl $\mathrm{J}$ Pharmaceut Sci Res 7 (5): 2201-2208.

Nara S, Ijong FG, Suwetja IK, Onibala H. 2013. Inasua, a fermented salted fish product from Central Moluccas. Aquat Sci Manag 1 (2): 160-164.

Pencreac'h G, Baratti JC. 1996. Hydrolysis of p-nitrophenyl palmitate in n-heptane by the Pseudomonas cepacia lipase: A simple test for the determination of lipase activity in organic media. Enzyme Microb Technol 18: 417-422.

Rashmi BS, Gayathri D. 2014. Partial purification, characterization of Lactobacillus sp. G5 lipase and their probiotic potential. Int Food Research J 21 (5): 1737-1743.

Rathi P, Saxena RK, Gupta R. 2001. A novel alkaline lipase from Burkholderia cepacia for detergent formulation. Pro Biochem 37: 187-192.

Salihu A, Bala M, Alam MZ. 2016. Lipase production by Aspergillus niger using shea nut cake: an optimization study. J Taibah Univ Sci 10: $850-859$.

Scopes RK. 1994. Protein Purification, Principles and Practice 3rd ed. Springer Verlag, New York.

Seiler H, Schmidt V, Wenning M, Scherer S. 2012. Bacillus kochii sp. nov., isolated from foods and a pharmaceuticals manufacturing site. Intl J Sys Evolut Microbiol 62: 1092-1097.

Sumarlin LO, Mulyadi D, Suryatna, Asmara Y. 2013. Identification of Potential Lipase and Cellulase on Waste of Skin Fruit by Fermentation. J Ilmu Pertanian Indonesia 18 (3): 159-166.

Thakur S. 2012. Lipases, its sources, properties and applications: a review. Intl J Sci Eng Res 3 (7): 1-29.

Wadia T, Jain SK. 2017. Isolation, screening and identification of lipase producing fungi from oil-contaminated soil of Shani mandir Ujjain. Intl J Curr Microbiol Appl Sci 6 (7): 1872-1878.

Xu Y, Wang D, Mu XQ, Zhao GA, Zhang KC. 2002. Biosynthesis of ethyl esters of short-chain fatty acids using whole-cell lipase from Rhizopus chinensis CCTCC M201021 in non-aqueous phase. J Mol Cat B Enzy 18 (1): 29-37.

Zouaoui A, Bouziane A. 2011. Isolation, optimisation, and purification of lipase production by Pseudomonas aeruginosa. J Biotechnol Biomater. DOI:10.4172/2155-952X.1000120. 